„Przekłady Literatur Słowiańskich”. T. 11, cz. 1, s. 1-22

ISSN 2353-9763 (wersja elektroniczna)

DOI https://doi.org/10.31261/PLS.2021.11.01.05

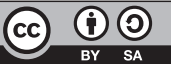

\title{
Wild about Wilde - The Translation of Oscar Wilde's Salomé in Croatian Literature of the Early 20th Century
}

\section{Wildemania - przekład Salomé Oscara Wilde’a a literatura chorwacka na początku XX wieku}

\section{Igor Medić}

iD https://orcid.org/0000-0002-2867-8767

\author{
GYMNASIUM CLASSICUM, ZAGREB \\ imedic85@gmail.com
}

Date of application: 15.01.2021 ～Date of acceptance: 22.02.2021

\begin{abstract}
The Irish writer Oscar Wilde was extremely popular in Croatian culture in the first decades of the 20th century. Although Croatian writers of that time generally did not read the original works of British authors but rather their translations, Wilde's popularity in Germany and Vienna sparked interest in his works among the Croatian readership and spectatorship. This paper explores the translation of Wilde's Salomé from German by Julije Benešić and Nikola Andrić, and the complex influence that this translation had on Croatian literature of early modernism, relying primarily on the interpretation of the same motif in the texts of young Fran Galović and Miroslav Krleža. The paper argues that the influence of Wilde's aestheticism is visible not only in the adoption of typical motifs, characters, or atmosphere but also in the autonomous and self-reflective language play in Krleža’s texts.
\end{abstract}

KEYWORDS | Oscar Wilde, Salomé, translation, Fran Galović, Miroslav Krleža 


\section{I}

A strong influence of Western European literatures and pluralism of styles are regularly emphasized in literary histories as the two key features of Croatian literature of the late 19th and early 20th century, i.e. of its early modernism. The influence of literary and cultural movements in Vienna, or more broadly, in Austrian and German literature, and the influence of French literature, via the works of Antun Gustav Matoš, undoubtedly affected Croatian literature in the first decades of the 20th century. The popularity of the works of the Irish writer Oscar Wilde in Croatia at that time is an extremely interesting literary and cultural phenomenon. After early essays on Wilde written by Matoš, and under the influence of Wilde's popularity in Germany and Austria, Wilde's works were translated into Croatian at a fascinating pace. In 1905, Julije Benešić and Nikola Andrić translated the seductive Salomé from German, and the play was performed for the first time in the same year in the Croatian National Theatre in Zagreb. That was only the beginning of a long and dynamic life of Wilde's plays in Zagreb: Lady Windermere's Fan, translated by Milan Bogdanović, was performed in 1907, A Florentine Tragedy, translated by Ivo Vojnović, was performed in 1908, An Ideal Husband, translated by Milan Šenoa, was performed in 1909, and The Importance of Being Earnest was translated by Milan Begović and performed in 1910. In those years not only did Wilde conquer theatre stages in Zagreb, but also, simultaneously, the first translation of The Picture of Dorian Gray was published in 1907, and many other translations of Wilde's stories, poems and aphorisms appeared in magazines. As Wilde became a synonym for aestheticism and decadence in the translations of the established Croatian writers and scholars, it is intriguing to look into the creative responses to the all-present fascination with Wilde of the younger authors from the beginning of the 20th century. ${ }^{1}$

This paper will analyse some of the ways in which, because of various text modifications, Wilde's Salomé fascinated the Croatian readership and theatre audiences at the beginning of the 20th century. Salomé is very interesting not only because of the fact that it is Wilde's first dramatic text translated for Zagreb and Croatian stages. The play sparked sensationalist interest in Wilde's supposedly scandalous life and attracted interest of the best writers in his enticing linguistic and stylistic finesse due to the attractiveness of the first performances on German and Austrian stages and due to the accompanying newspaper re-

1 For the review of the reception of Wilde's work see: I. Grubica, 2010: The 'Byron of Kipling's England': Oscar Wilde in Croatia. In: S. Evangelista, ed.: The Reception of Oscar Wilde in Europe, London, Continuum, pp. 270-285. 
views about his life and work. Since the Croatian translation of Salomé has not been analysed in depth, but was merely presumed to be based on the esteemed German translation by Hedwig Lachmann, the aim of this paper is to look at the structure and language of the Croatian translation with the basis on the German translation and then to explore the first journalistic responses to this stage phenomenon in order to show how the first spectator experiences of the performance, which charmed with the atmosphere and dramatic language, were transformed into newspaper reviews. Based on those insights, the final aim is to briefly interpret selected literary texts in which the impressions of the Zagreb performance resonate, and which contain Wildean intertext, which was introduced into Croatian literature at the beginning of the 20th century with the translation of the play, with its performances and with the accompanying journalistic reviews. All of this influenced the range of expressive possibilities of Croatian literary language and modernized its expression, as will be shown in the interpretation of the selected texts. Namely, young Fran Galović, one of the most important representatives of the Croatian literature of early modernism, under the direct influence of the Zagreb performance of Wilde's Salomé wrote two versions of the poem Saloma and the prose and lyric version of the play Tamara. At the same time, one of the most important and influential Croatian writers of the 20th century, young Miroslav Krleža, obviously fascinated by the popular character himself, designed the first version of his dramatic Saloma, the poem Saloma and a fragment about Scheherazade and Heliogabalus in his diary Davni dani (Bygone days). The paper will attempt to analyse a range of motif and text re-figurations, moving through a complex intertextual network created by intertwining translations, performances, accompanying reviews of the play's complex text and artistic responses to the fascination with Wilde.

\section{II}

Oscar Wilde wrote the play Salomé in French at the end of 1891 and published it in Paris and London in February 1892. In June 1893, Wilde informed Pierre Louÿs, who, as a native speaker, proofread the latest version of the text, that the title role would be played by Sarah Bernhardt, but the rehearsals at London's Palace Theatre were soon interrupted by censorship. The play was first translated into English by Lord Alfred Douglas and even though Wilde was not satisfied with it, that translation was published with the illustrations by Aubrey Beardsley in February 1894. The play was not premiered until the 11th February 1896 in French at the Théâtre de l'Euvre in Paris as a symbolist play 
directed by Aurélien Lugné Poe with Lina Munte in the lead role. ${ }^{2}$ In Germany, there were several premieres throughout 1901, but the most notable one was the private premiere directed by Max Reinhardt on the 15th November 1902 in Klaines Theater in Berlin. Reinhardt used Hedwig Lachmann's translation, as did Richard Strauss, who attended Reinhardt's premiere, and staged his extremely popular opera on the 9th December 1905 in Dresden. Salomé was performed on the 12th December 1903 in Vienna. The English premiere of Salomé took place on the 10th May 1905 and shortly after, the Zagreb premiere followed on the 27th May 1905, with the influence of the German and Austrian stages being crucial for the Croatian reception of the play. ${ }^{3}$

Wilde's name appeared in Germany at the beginning of the 1890s and the interest for his life and work gradually grew, especially after it was stirred up by sensationalist news about his trial and death. In literary studies, it is frequently emphasized that Wilde's popularity in Germany was all the greater the more he fell into oblivion in England. Patrick Bridgwater notes that the German craze for Wilde, however, was fuelled by the prevailing anti-British sentiments, so Wilde's media exaltation actually glorified the genius that was sacrificed by British philistines. It is important to emphasize that, in contrast to such an interest in sensations and pomp, the early Viennese reception was marked by an interest in Wilde's aesthetic theory, which was in line with the interests of the Francophile decadence of the Viennese fin de siècle. Hermann Bahr was the first to point him out, and the awareness about Wilde's work will later have an impact on the work of such famous writers as Hugo von Hofmannsthal, Stefan George and Thomas Mann. ${ }^{4}$ All that has been mentioned above is extremely important for the understanding of the reception of Wilde's work in Croatian literature. Croatia was, at that time, a part of the Austro-Hungarian Monarchy and Zagreb belonged to the Middle European cultural circle. Therefore, the artistic events occurring in Vienna at the end of the 19th and the beginning of the 20th century greatly influenced Croatian art, especially the works of younger authors, who often studied in Vienna. Also, the repertoire of the Croatian National Theatre in Zagreb was formed under the influence of Austrian

2 N. Kohl, 1989: Oscar Wilde: The Works of a Conformist Rebel. D. H. Wilson, trans. Cambridge, Cambridge University Press, pp. 176-180. About the English translations of the play see: J. Daalder, 2004: Which is the Most Authoritative Early Translation of Wilde's "Salomé"? "English Studies", no. 1., pp. 47-52.

3 See article by R. Vilain on Wilde's early reception in Germany and Austria, article by R. Kohlmayer and L. Krämer on Wilde on German stages, article by S. Mayer on Wilde on stages of Vienna and the article by C. Walton on Strauss' opera in the already mentioned essay collection The Reception of Oscar Wilde in Europe.

4 P. Bridgwater, 1999: Anglo-German Interactions in the Literature of the 1890s. Oxford, University of Oxford, pp. 44-73. 
and German stages. The most influential Croatian writer of that time, Antun Gustav Matoš, the author of the first two reviews of Wilde's life and work in Croatian magazines and newspapers from 1901 and 1902, who was introduced to Wilde's work in France, wrote his second review under the direct influence of André Gide's influential article Hommage à Oscar Wilde, first published in LEEmitage in June 1902, and later revised and translated into German in 1903. ${ }^{5}$ However, a strong impact of the German reception, both on stage and in the press, determined the audience's expectations, the reception of Salomé and other Wilde's plays, and often influenced the tone of the accompanying newspaper reviews and critiques.

After a thorough analysis of Hedwig Lachmann's translation, Rainer Kohlmayer stated that the English translation of the play was more important for the German reception of Wilde's Salomé than the French original. Lachmann published her translation in June 1900 in Wiener Rundschau magazine along with two Beardsley's illustrations and then in 1903 as a booklet with Marcus Behmer's illustrations. Max Reinhardt chose her translation as the basis for the 1902 staging with Gertrud Eysoldt in the main role, to which around 300 artists and critics from all over Germany were invited, including Stefan George and Richard Strauss. Afterwards Strauss used the same template for his extremely popular opera. Kohlmayer believes that the variety of translations and accompanying interpretations created one of the emblematic monstrous female characters of decadence on the European stage in the early 20th century: "The development of Wilde's Salomé from the French original into English, via Beardsley's drawings, Lachmann's translation, Reinhardt's production, i.e. Eysoldt's acting, shows a process of increasing radicalization and brutalization of the character of Salomé, who is removed from the historical context of early Christianity and shaped with increasing clarity into an icon of eruptive sexuality. This development reaches a peak in Richard Strauss' opera..."6

Kohlmayer thus interprets Wilde's French original as an antibiblical parable in which Jokanaan should not only be considered as Salomés victim but she should be equally considered as his. According to Kohlmayer, the play depicts Christian occupation of the ancient world - in the play young Salomé becomes a woman aware of her sexuality and embodies the resistance towards any prohibition of love, she is sensual, but not perverted. She refuses to suppress

5 I. Grubica, 2010: The 'Byron of Kipling's England'..., pp. 271-272.

6 R. Kohlmayer, 1995: From saint to sinner: The demonisation of Oscar Wilde's Salomé in Hedwig Lachmann's German translation and in Strauss' opera. In: M. Snell-Hornby, Z. Jettmarová, K. Kaindl, eds.: Translation as Intercultural Communication: Selected Papers from the EST Congress - Prague 1995. Amsterdam/Philadelphia, John Benjamins Publishing Company, p. 119. 
her own impulses and dies because of her passion in accordance with Jokanaan's orders to be beaten to death, which is ultimately done by Herod. It is worth mentioning that such an interpretation is in accordance with some of the traditional readings of Salomés character. For example, Norbert Kohl, in his study on Wilde, based on the French original, states that Salomé does not have a "cold-blooded desire to cause pain to others and to revel in their suffering, but is drawn rather as one possessed with passion, losing sight of reality through her manic eroticism, and in her blindness actually resembling Jokanaan, of whom she says: 'Tu as mis sur tes yeux le bandeau de celui qui veut voir son Dieu."'7 According to Kohlmayer, in contrast to that, Lachmann, with subtle changes in her translation, achieves that an unwavering femme fatale, in the German version of the play, steps onto the stage immediately. Therefore, he considers that Salomé's character in Lachmann's translation acquired a different personality, later further exaggerated on stage, because the translator used the English translation which was only partially adjusted to the French one, or used the French original simultaneously. Kohlmayer's analysis shows that Lachmann's undoubtedly marvellous translation is the result of a variety of choices between linguistic and stylistic possibilities in English and French versions and that it is enriched with new solutions which only appear in the German text of the play. Till now, it was presumed that the Croatian translation of Salomé by Julije Benešić and Nikola Andrić was based on Lachmann's translation. ${ }^{8}$ In the following part of the paper, this will be proven by searching the Croatian translation for Lachmann's key interventions in the dramatic text, to whose linguistic seductiveness and popularity on the German stages and in the European cultural space she strongly contributed. Moreover, the analysis of the stylistic features of the Croatian translation will serve as an excellent introduction into the interpretation of the structure of Wildean intertext in Croatian literature of the early 20th century.

7 N. Kohl, 1989: Oscar Wilde..., p. 184.

8 In his article Galovićeva Tamara $i$ Wildeova Saloma, which explores the influence of Wilde’s Salomé on Fran Galovićs Tamara, Nikola Batušić presumed that Wilde’s play was translated from German by the actress and translator Nina Vavra, Josip Bach's wife, (pp. 51), but Irena Grubica stated, based on her inspection of the manuscript of the translation, that the play was translated from German by Julije Benešić and Nikola Andrić, and only assumed that they had used Lachmann's translation (p. 274). 


\section{III}

The manuscript of the translation of Wilde's Salomé has 28 unnumbered pages. At the bottom of the last page, it is noted that it had to be translated by two translators due to urgency - the first half was translated by the author and linguist Julije Benešić, while Nikola Andrić, author and playwright, translated the other half - and that the translation was finished on the 11th May 1905, not long before the Zagreb premiere on the 27th May 1905. The text of their translation became available eight years later when Nikola Andrić included the translation of Salomé under the title Sablast od Cantervilla (The Canterville Ghost) in the 4th volume of Zabavna biblioteka (Entertaining library), published in 1913, alongside the story from the title, The Sphinx without a Secret, The Fisherman and His Soul, The Nightingale and the Rose, The Happy Prince, Poems in Prose, and selected aphorisms from Wilde's works.

Comparing Lachmann's translation with the French and English versions, Kohlmayer indicates that Lachmann skilfully avoided the archaic intonation of the English translation, which brings it closer to the French original in which characters speak in everyday speech. Also, in comparison with the French version, Lachmann enriched the character's speech lexically, thereby further nuanced the language of the play by creating a sublime form of the German language of that time, which seems dramatic thanks to variations of expressions and repetitive sentences and thanks to the skillful compounding and a dynamic rhythm of the translation. Kohlmayer believes that one of the shortcomings of the translation is that the motif of the Moon is not personified as a female being with the same ease as it is in the French and English texts, where it is transformed into an important symbol already at the beginning of Wilde's play. Moreover, even though in the French original Salomé addresses Jokanaan intimately, in the second person singular, while she keeps other characters at a distance by addressing them in the second person plural, Lachmann introduces the same directness in the conversation of the Young Syrian and the Page of Herodias, in Salomés thrice repeated request to the Syrian that he should let Jokanaan out of the cistern and in Salomés addressing Herod when she demands that he fulfil the oath. Eventually, Kohlmayer considers it a shortcoming that in Jokanaan's third line, the lexeme mermaid is replaced with the lexeme nymph, thus losing parallelism with the motif of the centaur in the same sentence, with which Wilde, according to Kohlmayer, implies the coexistence of a hidden, mythical world of nature intertwined with the human beneath the surface of the Christian world: "For the centaurs and sirens, the mythical symbols of the male and female union of humans and animals, the beginning of Christianity ushered in the panic of the apocalypse. The destruction of ambiguities, of the unity of body and soul, 
of the polyphony of antiquity, now continues resolutely in the liquidation of Salomé."' It is also interesting, and important for the interpretation of Salomés character, that the last sentence spoken by Salomé, in which she addresses Jokanaan's severed head at the end of the play, is omitted - "Il ne faut regarder que l'amour," i.e. "Love only should one consider." Lachmann's translation, unlike the French original and the English version, ends with an enigmatic statement which precedes the omitted sentence, that the mystery of love is greater than the mystery of death. Kohlmayer believes that the reason for omitting the last sentence is that Salomé, opting for love, would seem too harmless, which does not fit in with the notion of a monstrous femme fatale who, because of her perverted passion, demands that the prophet be beheaded: "The dialectic relationship between Jochanaan and Salomé does not come to her (Lachmann's) mind. In and since Lachmann, as Jochanaan does not call for lynch law with regard to Salomé, Jochanaan embodies solely the passive purity of a Christian prophet detached from the world, so that, for the theatrical reception of the characters as well, the simple dichotomy of whore and saint had to impose itself." ${ }^{10}$

The interpretation of the translation by Benešić and Andrić indicates that they followed Hedwig Lachmann's translation in all the details. It would be interesting to know which version they used exactly, since the 1903 edition was illustrated by Marcus Behmer, a great admirer of Audrey Beardsley, who found inspiration for the illustrations not only in the works of the British painter but also in the German translation of the play and this accompanying visual equipment could have influenced the visual aspect of the Zagreb premiere. ${ }^{11}$ Unusual metaphors, similes and poetic imagery, with which Wilde's texts dazzled the readers, were skilfully transported from the German version into the Croatian one and are especially highlighted in the remarks, which, in such a style, aptly express the almost narcotic fascination of the characters with the motifs they speak of or with the interlocutors addressed by the unheard. For example, different character's descriptions of the Moon, Jokanaan's speech, Saloma's responses to Jokanaan and Saloma's final monologue, in which she addresses Jokanaan's head, were modelled in such a way. Jokanaan's replies, especially in the first part of the play, are reminiscent of the biblical style, not only because of the content but also because of the many adjectives in the inversion and because of parallelism, so they differ from the rest of the text. Herod's extensive conversation with the Jews, the Nazarenes and the Roman Tigellinus about the

9 R. Kohlmayer, 1995: From saint to sinner..., p. 112.

10 Ibidem, p. 119.

11 For more information about the premiere see: N. Batušić, 2000: Galovićeva Tamara $i$ Wildeova Saloma, p. 51. 
prophet's words is the least poetic and stylistically marked part of the whole play, and therefore it most resembles everyday speech, which emphasizes even more that the prophet's voice and the conversation of the gathered belong not only to different languages, but also to different worlds. It is symbolic that only Saloma, with the stylistic nuance of her replies, can match the prophet's expression, since, after all, she is attracted to his voice from the beginning. Therefore, by finding the equivalent idioms in its own plethora of linguistic codes, the Croatian translation achieves the praised lexical richness and complexity of the German version. The whole translation is formed as a kind of a linguistic collage, which was acknowledged in Wilde's original already in one of the first reviews of the French drama, which called it a "mosaic" and an "Island of Voices." ${ }^{12}$ As it happened in German literature, thanks to Lachmann's translation, an unusually rich and often surprising expression is thus introduced into Croatian literature, which is associated not only with Wildean style but with the poetics of aestheticism in general.

Following Kohlmayer's analysis of Lachmann's text, two details are quite interesting in the Croatian translation. Benešić and Andrić, under the influence of the German version, kept a great number of relations in which the characters address each other in the second person singular, in that way minimizing the distance between Saloma and most of the characters which exists in the original. Second person singular is not only used by Saloma when addressing Jokanaan, but also by the Page of Herodias when he talks to the Young Syrian, by Saloma when she pleads the Syrian to bring Jokanaan from the cistern, and by Saloma when she demands for Jokanaan's head on a platter from Herod. Such a modification is very interesting in the conversation between the Page and the Syrian because it further emphasizes their intimacy, especially when the Page is mourning the death of the Syrian by pointing out that he was more than a brother to him. Possible meanings of these remarks could not have been ignored even in the Croatian translation, especially because the reasons why Wilde was sentenced to prison were frequently reported in the newspapers. However, these allusions, amplified by Lachmann's translation, were obviously considered to be the part of the charm of the forbidden drama. The translation of Jokanaan's threat, which Herodais considers to be aimed at her, is also interesting. Kohlmayer believes that Lachmann is minimizing Jokanaan's role in Saloma's death by translating his words as a prophecy, as a description of a death which will be caused by the crowd and army generals, while in the French

12 Anonymous critic from the Pall Mall Gazette, 27th February 1893, p. 3. In: K. Beckson, ed., 2005: Oscar Wilde: The Critical Heritage. London and New York, Routledge, p. 155. 
original and in the English translation it was clearly stated that Jokanaan himself calls for and orders the harlot's execution by stoning, stabbing and crushing to death with shields. The Croatian translation appears to be hesitant between these two options by creating gradation using grammatical devices - stoning is presented as a future action executed by the crowd ("Ovo veli Gospod Bog naš: skupit će se svjetina proti njoj. I uzet će kamenje i kamenovat će ju...”) [This says our Lord: a crowd will gather against her. And they will take stones and stone her...], ${ }^{13}$ but in the next reply, the future action attributed to the army generals was later on, in the manuscript, changed into an imperative ("Vojskovodje neka je probodu mačevima i zgnječe štitovima svojim.") [Let generals stab her with their swords and crush her with their shields.], ${ }^{14}$ while Jokanaan's orders culminate with the third reply, in which the prophet only seems to become the agent of the action while actually retelling the prophecy ("Tako hoću da zbrišem sa zemlje sva nedjela...") [So I want to erase from earth all misdeeds...]. ${ }^{15}$

After comparing the translation of Benešić and Andrić with Lachmann's interventions in the play, it is worth looking at the texts that were published in the time of the Zagreb premiere in 1905 and which reveal a lot about the theatre play and its direct effects on the viewers of that time and on the first experiences and interpretations of Saloma's character. Thus, we will connect the translation of the play with yet another transformation of the text, the transformation of the text of the play into an elusive theatrical act, which can be partially reconstructed only by looking into the recorded impressions and reviews it provoked. Also, the analysis of the stylistic features of certain records will show how the famous performance of an even more famous writer influenced not only the audience's feelings but also their style.

\section{IV}

The Zagreb premiere of Wilde's Salomé was held on the 27th May 1905, so the date roughly coincided with the tenth anniversary of Wilde's conviction. ${ }^{16}$ Josip

13 Quotes from the play are taken from the manuscript of the translation which is kept in The Institute for the History of Croatian Literature, Theatre and Music of the Croatian Academy of Sciences and Arts in Zagreb, p. 17. If it has not been noted differently, the quoted excerpts from the play are the same in the version of the play published in 1913.

14 Ibidem.

15 Ibidem.

16 It is also important to note that 1905 was an important year for the reception of Oscar Wilde because of Richard Strauss's operatic adaptation of Salomé (ten years later, on 15 May 1915 Strauss's opera premiered at the Croatian National Theatre in 
Bach, who directed the play and who later became the director of Drama in the Croatian National Theatre, was the most responsible for the fact that the Croatian National Theatre, with its repertoire, kept up with the current trends. The play was such a success that by 1920 it was staged 12 times. Invited by the intendant Adam Mandrović, the main role was played by the guest Hermina Šmovska, who started her career in Zagreb, but was a member of the Berlin Schillertheater from 1897, and later of the Zurich Stadtheater. ${ }^{17}$ It is interesting that two announcements of the play, one anonymous in Narodne novine (National newspaper), the other by the translator Julije Banešić in Obzor (Horizon), not only present Wilde and Saloma, but also emphasize the stylistic refinement of his work. Despite being spiced up by, for that time, the inevitable, obscure curiosities about Wilde's life, such as the speculation that the author was poisoned to death with an oyster, the anonymous announcement of the premiere, when presenting the text, shifts the emphasis from the content to the form stating that even though the play is "nothing more than a dramatization of a biblical scene," such a dramatization "could only have been written by one of the most refined modernists" and that the extraordinary success lies not in the plot but in the fact that it marks the pinnacle of Stimmungskunst, "which experienced the most romantic triumphs in this drama with the unusual picturesqueness of the language, the oriental diversity and the richness of the light arrangement." ${ }^{18}$ It is important to remember that Reinhardt's play was designed as an example of postnaturalist theatrical aesthetics, by adapting the text to the atmosphere, colour, music and overall visual impression, and that the actress Gertrud Eysoldt, who embodied Salomé as a femme fatale, later played the equally dangerous and perverted Wedekind's Lulu and Hofmannsthal's Elektra. ${ }^{19}$ The extensive announcement by Benešić, published in Obzor (Horizon) on the day of the premiere, is a dramatically composed text which begins with an upsetting sentence about the author: "He was called the 'king of life' and 'king of paradox', but he died as a slave of shame, murdered by English philistines." ${ }^{20}$ From the first to the last sentence, the translator's text echoes German newspaper topos about Wilde as a misunderstood genius and a victim of English bourgeoisie. It seems

Zagreb and the translation by Andro Mitrović was published) and because of Robert Ross' publication of De Profundis and its German translation by Max Meyerfeld.

17 N. Batušić, 2001: Morbidna erotika..., pp. 234-235.

18 Anonymous, 1905: Oskar Wilde, pjesnik Salome na hrvatskoj pozornici. Narodne novine, Zagreb, 24 May, pp. 3-4 (translation).

19 R. Kohlmayer and L. Krämer, 2010: Bunbury in Germany: Alive and Kicking. In: S. Evangelista, ed.: The Reception of Oscar Wilde in Europe. London, Continuum, pp. $270-285$.

20 J. Benešić, 1905: Oscar Wilde. “Obzor”, Zagreb, 27 May, pp. 1-2 (translation). 
that the condemnation of the English attitude towards Wilde in Benešićs text is an expression of sincere affection for the writer, whose work, judging by the quality of the analysed translation and the exhaustiveness of the information presented in the announcement, he was well acquainted with. At the end of the text, Saloma is announced as "a strong play, and above all artistic to the extreme, perfect in every detail of the most insignificant scene, created by a man who was an artist in his every vein" 21 and in which Saloma "is a raging passion, demon, monster. She loves Jokanaan fervently more out of spite than heart. In her lust, she regrets the brutal pleasure because she feels some kind of a high passion, ecstasy, maybe even Wilde's romanticism." ${ }^{\text {"2 }}$ While he is announcing "maybe the most interesting premiere from foreign literature of the season generally," ${ }^{\text {"23 }}$ it is clearly evident that Benešić is fascinated with Wilde and the stylistic virtuosity of his works, which is also praised in the Narodne novine (National newspaper) announcement. This is important because it shows that Wilde's Salomé was not advertized as a fashionable stage scandal, but as a perfectly refined aesthetic artifact which transforms into an extremely enticing drama of atmosphere. Also, the depiction of Saloma's character by Benešić testifies that the translator himself perceives her character first as a demonic femme fatale, in accordance with the dominant German interpretation based on Lachmann's translation. Immediately after the premiere, at least three reviews of Bach's interpretation of Wilde's play could be read in Zagreb newspapers, all of which suffered from the intoxication with the refinement of Wilde's style and enthusiasm about the performance of Hermina Šumovska.

An eighteen-year-old Fran Galović also sat in the packed audience at the premiere, as evidenced by the notes from his theatre diary. Not long after viewing the play, Galović, inspired by the Zagreb premiere of Saloma, wrote a poem of the same title. Later on, in the preface to Galovićs collected works in 1940, that poem will be mentioned by Benešić as the most mature poem of his early work. A significantly modified version of the poem from 1910 was published in Mlada Hrvatska (Young Croatia) magazine in 1911. The first version of the poem from 1905 is an interesting example of an impressive stage scene transformed into a rousing lyrical work. The poem consists of five quatrains dominated by 14-syllable verses and only even verses systematically rhyme. In the poem, Galović depicted the most disturbing scene in which Saloma kisses Jokanaan's severed head on a silver platter. Even though in the play Saloma utters one of the most dramatic and stylistically most nuanced monologues, which is

21 Ibidem.

22 Ibidem.

23 Ibidem. 
faithfully depicted in the Croatian translation, Galovićs Saloma does not talk at all, she observes, kisses and caresses Jokanaan's face and hair, and even lifts his eyelids, all while being silent in a static lyrical picture. The language of the poem is simple in comparison to the language of the Croatian translation of Wilde. Galović does not reach for the typical Wildean motifs - the motif of the Moon does not appear in the poem - he does not imitate his similes and metaphors nor builds an image of exotic motifs even though in the fourth stanza, the final thought of Saloma's monologue is paraphrased (“...et le mystère de l'amour est plus grand que le mystére de la mort"): "Misterij tajni, vječni oćutila je tada / kad ljubljaše mu usne, sve pune svježe krvi; / misterij kojim ljubav obaspe svako biće, / kad ćuti njene slasti užitak tajni, prvi." [A secret mystery, eternal, she felt then / when she kissed his lips, full of fresh blood; / the mystery with which love overwhelms every being, / when it senses the first secret pleasure of its sweetness. $]^{24}$

The second version of this poem, written five years later, can be read as a new interpretation of the same motif. The second Saloma consists of three quatrains written in shorter verses, denser and more dynamic than the first, and by putting the readers in a position in which they have to sense what is left unsaid and hidden between verses, it expresses the mysterious atmosphere of the terrible sight more skilfully. The other Saloma is a foreboding poem in which the reader, Saloma and the members of the royal court can merely presume what the source of discomfort in the night darkness that surrounds them is. That way, the poem better reflects Saloma's impenetrable and incomprehensible lust to the reader and viewer of Wilde's play, but also better expresses Saloma's anticipation of her own new impulses, which overwhelm her as soon as she first hears Jokanaan's voice at the beginning of the play. Twenty verses of the first poem were condensed into the first quatrain of the second poem in a way that the whole scene of kissing the prophet's head was reduced to the key motifs using elegant chillness: "I stajala je sama u ponoć pod palmom - / I upirući pogled u mrtvo, krasno lice / Cjelivala mu usne i toplu krv i suze / I gladila mu rukom svilne trepavice..." [And she stood alone at midnight under a palm tree - / Staring at the dead, beautiful face / She kissed his lips and warm blood and tears / And stroked his silky lashes with her hand... $]^{25}$ The second stanza is marked with a simile - Salome is presented as a Saronic rose which flutters in the night wind and dreams about a painful love in snowy moonlight. That impressive scene does not only evoke Wilde's typical motifs but also his unusually poetic similes, as well as in the final verses in which rays of moonlight are shining over

24 F. Galović, 1940: Pjesme Frana Galovića. Zagreb, Binoza, p. 128 (translation).

25 Ibidem., p. 189.

\begin{tabular}{l|l} 
PLS.2021.11.01.05 | s. $13 \mathrm{z} 22$ &
\end{tabular} 
the royal home like a horrible apparition of death. Modelled as a poem of eerie atmosphere and subtle eroticism, the second Saloma by Galović is an extremely interesting lyrical transformation of the play. Moreover, the comparison of the two lyrical Salomas by Galović demonstrates the development of the poet's expression and the complex effects that Wilde's intoxicating text gradually had on refining the literary language of Croatian modernism.

At the beginning of May 1906, Galović wrote his first published play Tamara in prose, which he will later transform into a version in verse. This other version was staged in the Croatian National Theatre in Zagreb on the 12th September 1907. The play was written by interpreting the motifs from Lermontov's poem, but Nikola Batušić, in his analysis, shows that Galović undoubtedly inherited a lot from Wilde's morbid erotica in Salomé. This is shown in the lavishly conceived scenography full of secessionist props, in the shaping of the main heroine as a typical femme fatale, a seductress who is rejected and seeks for revenge, and thus a particular Stimmung reminiscent of Wilde's play was created. ${ }^{26}$

\section{V}

At the end of May 1906, Wilde’s Salomé was again staged in Zagreb. At that time, Isa Grégorova played the main role. Two reviews of that play express opposing views of the actress' performance. While the critique in Hrvatstvo (Croatism) paper considers Grégorova's performance as significantly weaker, both in acting and in dance, than the last year's performance by Hermina Šumovska, Vladimir Lunaček, author and theatre critic, wrote his review of the actress' performance as a suggestive artistic text in newspaper Obzor (Horizon). According to Lunaček, Saloma at first seemed as if she was haunted by a demon on the stage, and then she gradually changed into a bloodthirsty monster:

Vidite li tu pantersku spodobu, što lako potiskuje svoje sandale sa vrućeg kamena tla, kako se šulja u srce Herodovo, da mu ga izgrebe oštrim plamsajem svojih očiju. Jeste li sliedili okom gdjicu Grégrovu kako se šulja u njega pod sjenom palma, a u svjetlu mjesečeve krvi. Jeste li ju vidjeli, kako mu je razdirala grudi, zagledala u kraljevo srce tražeći Johanaana. [...] Noge su joj otežčale i tromo se povlače tlom, ramena joj zadrktala kao krila leptirova. Nasmije se na pola ludim smiehom, u njenom grlu zvjersko rikanje užitka, težak disaj i sve tiše i tiše biva oko nje, a sve laglje stišava bura u njoj. Izgara veliki jedan plam na oltaru vječnog užitka.

26 See: N. Batušić, 2001: Morbidna erotika..., pp. 234-235.

\begin{tabular}{l|l} 
PLS.2021.11.01.05 | s. $14 \mathrm{z} 22$
\end{tabular} 
[Do you see that panther figure, who easily pushes his sandals off the hot stone ground, sneaking into Herod's heart, to scratch him with the sharp flame of his eyes. Did you follow Miss Grégorov with your eye as she crept into him under the shadow of the palm trees, and in the light of the Moon's blood. Did you see her tearing at his chest, staring into the king's heart looking for Johanaan, [...] Her legs were heavy and they were slowly dragging on the ground, her shoulders twitching like butterfly wings. She laughs half-madly, a beastly roar of pleasure in her throat, a heavy breath and it gets quieter and quieter around her, and the storm in her calms down. A great flame burns on the altar of eternal pleasure. $]^{27}$

The description by Lunaček shows the author's fascination with the actress's performance and the obsession with the demonic and monstruous nature of the femme fatale in such a way that the popular literary character and one of her stage interpretations for him become a canvas on which many of fin de siècle pseudoscientific and popular-culture notions about women are projected. ${ }^{28}$ Such a stylistic outburst of the critic's almost voyeuristic enthusiasm for the performance, in which it seems that the dangerous spectators lurked in the darkness from both sides of the stage, evokes two more interpretations of Salomé by Miroslav Krleža. In June 1914, the 21-year-old Krleža took the text of his play Saloma to Josip Bach, the director of Drama in the Croatian National Theatre in Zagreb, but it was rejected as well as his other early plays, after which he rewrote the text several times and published it in 1963. His lyrical Saloma, Krleža published in the Savremenik (Contemporary) magazine in 1918 and then the next year in his collection Pjesme III (Poems III). Based on the structure of the poem and the motifs, Zoran Kravar concludes that the lyrical text, as well as the play, was revised many times, perhaps in the period from 1914 to $1918{ }^{29}$ In the poem, a Roman officer Kajo is courting an indifferent Saloma, depicted as a femme fatale with whom Kajo is completely enamoured. Kravar states that such a male-female pair is present in several works by Krleža, out of which the most famous one is Baločanski and Bobočka in Povratak Filipa Latinovicza (The Return of Philip Latinovicz), but he does not mention another Krleža's pair, Scheherazade and Heliogabalus, depicted in one entry of the diary Davni dani (Bygone Days). It is interesting that the description of Saloma in the poem

27 V. Lunaček, 1906: Gostovanje gđice Ise Gregrove. “Obzor”, Zagreb, 24 May, p. 9.

28 For the overview and the analysis of the selected dramatic femmes fatale characters, including Krležàs Saloma, in the first three decades of 20th century in Croatian literature see: L. Čale Feldman, 2012: U san nije vjerovati. Zagreb, Disput, pp. 189-204.

29 Z. Kravar, 2001: Antički i moderni eros u lirskoj Salomi. In: N. Batušić, Z. Kravar, V. Žmegač: Književni protusvjetovi. Poglavlja iz hrvatske moderne. Zagreb, Matica hrvatska, pp. 169-172. 
unusually reminds of Lunaček's depiction of Salomé in Wilde’s play. Namely, both were shown as exotic beauties under the hot eastern sun, both pulsate with life energy, both are compared to predatory animals in need of blood and connected to other natural motifs and motifs of fire and flame are used in the depictions of both - Krležàs Saloma "with a gesture of a young tigress and woman / she drinks Kajo's blood / in the salty flames of a raving fire," 30 "as fruit Saloma's body smells / and her thighs and breasts are still burning with Roman blood." ${ }^{31}$

What the correspondence of the two descriptions of the fammes fatale depicted as an exotic and irresistible predator under the hot eastern sun suggests is not that Krleža directly borrows elements of Lunaček's portrayal or of any other similar portraiture that could easily be found in literary and non-literary texts of the time, but that he implicitly refers to all of them, creating the character in his poem as a hyperbole and a collage of typical and easily recognizable motifs and stylistic features, spiced up with his own poetic twists. As the analysis of Krleža's dramatic Saloma has already shown, Wilde's influence is not traceable only in the re-writing of the famous story about the infamous fatal woman, but equally in the staging of the language play in the text which becomes self-conscious of its own textuality, mostly due to Saloma's character. ${ }^{32}$ The secret of her inexplicable attraction, and of the privileged insight that only she possesses, can thus be interpreted as her mastery of the language and consciousness that the world which she and other characters inhabit is nothing more than an assemblage of words and typical motifs, so common that they have, as we have seen, spread out of literary works into the wild, into the newspaper articles and everyday speech. Krleža's poem is introduced as a fragment, a piece of a larger text, incomplete and unsatisfactory for a reader who wants - just as Kajo in the poem - the whole Saloma/Saloma. But this wish will remain unfulfilled because in the end he is the one who is conquered by the insatiable woman, just as the reader is bewildered by the indecipherable poem. The first stanza depicts the scenery in a way that the reader is unable to dive into the fictitious world of the poem and must be aware that what he reads is constructed out of words. This is not achieved only with the irregular and a bit strange rhyming, but also with the repeating of the first verse of the stanza as the last one, with

30 M. Krleža, 1969: Poezija. Zagreb, Zora, vol. 26., p. 97 (translation).

31 Ibidem, p. 99.

32 For the analysis of Wilde's influence in Krleža's play, which is traced not only on the level of motifs and plot, but even more on the level of Krleža's and Saloma's relationship towards language, based on Wilde's insights about the complex interconnection between form and content, see: I. Medić, 2017: Zavodljivi jezici - Krležina "Saloma" i vajldovski esteticizam. "Umjetnost riječi”, vol. 61., no. 1./2., pp. 87-111. 
a different word order producing a different rhythm: $U$ vrijeme je ono tiha jesen bila. - Jesen tiha bila $u$ vrijeme je ono meaning that It was a time of a silent autumn. Repeating the line with a changed sequence of the words indicates that the landscape is only a setting made of words, and that it can easily be rearranged in different ways. Similarly, in the final stanza the scenery will be depicted by alluding to the Herod's palace, reminding us once again that the world in the text is a world from another text, Krleža's play, which itself rewrites and deconstructs another one, that of the Wilde's play, which itself, as we have highlighted, seemed to its first readers to be a "mosaic" and an "Island of Voices". In the second stanza Saloma is constructed as a conglomerate of words which refer to fire and flame, as a pile of synonyms, depicting her as a metaphorical pyre of passion on which Kajo will burn out. When Kajo later speaks, he describes himself and Saloma while using the motifs from the poetic register of literary vitalism, one of the styles and popular poetic choices in the Croatian literature of the early modernism in the beginning of the 20th century. Indeed, Kajo's speech is so richly ornated with the imagery typical of vitalism that, when he invites Saloma to join him in celebration of the ancestress earth who can heal all the pain, he sounds like the cricket from the famous dithyramb Cvrčak (The Cricket) by Vladimir Nazor, an emblematic poem written in the spirit of vitalism and published in 1910. Unfortunately for Kajo, as we have seen, Saloma seems to be perfectly aware that the earth that he so passionately exalts is as fictitious as everything surrounding them, because her first spoken words are: "Sve to je Ništa! / Sve to je samo skvrčen ludi grč! / Sve cjelov je i krv, i meso, i praznina! / I sve je samo bol, bol ranjenih živina, / I nema sna, ni omame, ni vina!" ["All of it is Nothing! / All of it is only convulsed spasm! / All is but a kiss, blood, flesh, and emptiness! / And all is just pain, pain of wounded animals, / And there is no dream, no illusion, no vine!"] ${ }^{33}$ As she embraces Kajo's pleas, it is said that she "knits the threads from all the weavers and from all the Arachnes, / and while her whole body burns like a fiery poppy, / the tissue of the invisible net falls." ${ }^{34}$ The archetype of a woman as a weaver is thus, by an allusion to the Greek myth, transformed into a wicked female monster who captures and traps the oblivious male, but not only that, because the allusion to the etymology of the word text is also clear, as the textus is also woven. Saloma, as a cunning spider-women, is thus shown as the master of the language and of the text, so while Kajo, who had led whole legions of veterans in death, is intoxicated and dazed under Saloma's feet as "a spring his benumbed speech burbles, / filled with stars and lies, wisdoms and smoke, / filled with pain and sad old

33 M. Krleža, 1969: Poezija. Zagreb, Zora, vol. 26., p. 98 (translation).

34 Ibidem, p. 100.

\begin{tabular}{l|l} 
PLS.2021.11.01.05 | s. 17 z 22
\end{tabular} 
rhymes." ${ }^{35}$ In the end, Kajo's speech is nothing more than sad old rhymes, like the ones he perorated while using the typical motifs of vitalism. Krležas Saloma thus becomes a spider-like creature lurking from the nets of texts, numerous intertwined texts of early Croatian modernism which re-write and re-inscribe her as an exemplary figure of femmes fatale forming the complex web of Wildean intertext.

It is then not surprising that in the prose fragment of the diary Davni dani (Bygone Days), under the date of the 2nd May 1916, the narrator imagines another exotic eastern story with another fatal mistress of language at its centre: "ja pišem (u mislima) svoju Šeherezadu, na uspomenu Oscara Wildea i u čast Bakstovu. (...) Napisao bih posljednju noć u ,Tisuću i jednoj noći', kada je Šeherezada ispričala Velikom Padišahu svoju posljednju legendu i kada se taj lirski opijum pretvorio u strašnu zbilju stvarnosti." [I’m writing (in my thoughts) my Scheherazade, in the memory of Oscar Wilde and in Bakst's honour. (...) I would write the last night of 'One Thousand and One Nights', when Scheherazade told the Great Padishah her last legend and when that lyrical opium became the terrifying reality. $]^{36}$ Scheherazade, "a cunning and sly sorceress, ingenious poetess," ${ }^{37}$ stunned the monstrous autocrat Heliogabalus, who embodies all that is "blind, beastly and unhuman" in a man and what is called "officer's satrapy", ${ }^{38}$ with her intoxicating narration of the stories, which Krleža described weaving his depiction as an exotic carpet made of interlocked Wildean arabesques, to which the play was also compared in one of the first reviews of the Zagreb premiere of Wilde’s Salomé: "Ova je drama pjesma. Pjesma strasti... bogati sag najoprečnijih čuvstava." [This play is a poem. Poem of passion.... a rich carpet of the most transverse feelings $]^{39}$ Scheherazade "narrates about the stars so confidently and sublimely," and her fingers are described as "Arachne-like", ${ }^{40}$ so she reminds us of Krleža’s Salomas. In the end of Krleža’s, and in end of Scheherazade's tale, as the magic of the story - and of the Wildean imagery that was interweaved into it - starts to fade, she informs Heliogabalus that she has infected him with leprosy. Scheherazade thus proved her mastery in storytelling defeating the cruel ruler with a craftly knitted fantastic tale, which Krleža decided to knit in a manner of Wilde, because there is obviously no

35 Ibidem, p. 101.

36 M. Krleža, 1956: Davni dani: zapisi 1914-1921. Zagreb, Zora, vol. 11-12, p. 151 (translation).

37 Ibidem, p. 153.

38 Ibidem, p. 152.

39 Anonymous, 1905: Saloma od Oskara Wildea - Zahtjevi morala od O. E. Hartlebena. Obzor, Zagreb, 29 May.

40 M. Krleža, 1956: Davni dani: zapisi 1914-1921. Zagreb, Zora, vol. 11-12, p. 153. 
other language as narcotic as his, no style more apt for a fictional text aware of its fictionality - a tale about a tale within a tale. After this story the narrator in the diary abruptly comments that he had already written a series of Wildean variations of same sort and mentions his first published play Legenda (Legend) and his play Saloma. ${ }^{41}$ He then distances himself from the idea of writing new variations on Wilde and distances himself from Wilde claiming that all of it is just writing following a template and stating that to free oneself from the template in literature means to be or not to be. But it is questionable if Krleža really did renounce Wilde and Wildean aestheticism as easily as the narrator of his early diaries claims he did in 1916.

\section{VI}

In the texts before us, a mysterious demonic woman is gradually transformed into an enigmatic creature which rules not only the secrets of love and sexuality, but also the secrets of language. It seems that Wilde's Salomé, who in the French original, fascinated by Jokanaan's words, becomes aware of the dark mystery of love and passion, from a suit tailored out of the models and patterns from (the German translation of) Wilde's motif-style catalogue gradually suits up into a new refined rhetorical attire, transforming into the embodiment of life force appropriately shaped by motifs and procedures from the vitalism's style catalogue. $^{42}$ It is important to notice, however, that, at least in Krleža's texts, Saloma's character (and similar characters) inherit not only the notorious status and luxurious verbal attire, but also Wilde's awareness of the slippery-slopes of language and of its powers to create reality. Elements of both of those registers, Wildean aestheticism (partially comparable with secessionist style) and literary vitalism, into which parts of Wildean intertext were also gradually translated

41 In his first published play Legenda (1914) Krleža also refers to Wilde’s Salomé making the antagonist (the Shadow of Jesus) a spectator of the Biblical/Wildean play who remembers the dance of the seven veils and describes Salomés kissing Jokanaan's severed head.

42 For the analysis of the trends which form stylistic pluralism of Croatian modernism see: V. Žmegač, 1997: Duh impresionizma i secesije. Studije o književnosti hrvatske moderne, Zagreb, ZZKFFSZ. Žmegač compares certain Wilde's aesthetic proclamations with the features of the secessionist style of the Viennese fin de siecle, but the analysis presented in this paper shows that Wilde's style, at least when it comes to Salomés discourse, was gradually also translated into the language of vitalism in Croatian modern literature. About vitalistic layers in certain Krleža’s works see: Z. Kravar, 2005: Svjetonazorski separei. Antimodernističke tendencije u hrvatskoj književnosti ranog 20. stoljeća, Zagreb, Golden marketing i Tehnička knjiga. 
and modified in Croatian literature of early modernism, will be a vital part of Krleža's works long after the initial fascination with Wilde has disappeared, and those residues can be read as many different signs of Wilde in Krleža's work. For instance, certain novellas from the Glembay cycle will be draped with aesthetic wallpaper, novel Povratak Filipa Latinovicza (The Return of Philip Latinovicz) (1932) will be filled with the remnants of aesthetic and vitalist motifs, and Leone's judgement of Baroness Castelli's charity work in the play Gospoda Glembajevi (Messrs. Glembay) (1928) will even bring to mind Wilde's criticism of charity from the essay The Soul of Man Under Socialism. With Krleža in mind, especially in comparison with Galović, it can be seen how different and long-lasting the multiple effects of translations of certain works can be and how complex the stylistic and poetic transformations and re-figurations can be initiated by their authors, or even just notions about them, thus permanently modernizing a particular literary space.

\section{Literature}

Anonymous, 1893: Pall Mall Gazette, 27 February, p. 3. In: K. Beckson, ed., 2005: Oscar Wilde: The Critical Heritage. London and New York, Routledge, pp. 155-157.

Anonymous, 1905: Oskar Wilde, pjesnik Salome na hrvatskoj pozornici. "Narodne novine", Zagreb, 24 May, pp. 3-4.

Anonymous, 1905: Saloma od Oskara Wildea - Zahtjevi morala od O. E. Hartlebena. "Obzor", Zagreb, 29 May.

Batušić N., 2000: Galovićeva Tamara $i$ Wildeova Saloma. In: B. Hećimović, ed.: Krležini dani u Osijeku 1999. Hrvatska dramska književnost i kazalište i hrvatska književnost. Zagreb/Osijek, HAZU, pp. 50—54.

Batušić N., 2001: Morbidna erotika Galovićeve Tamare. In: N. Batušić, Z. Kravar, V. Žmegač, eds: Književni protusvjetovi. Poglavlja iz hrvatske moderne. Zagreb, Matica hrvatska, pp. 234-235.

Benešić J. and N. Andrić, 1905: Saloma (manuscript of translation). Zagreb, Zavod za povijest hrvatske književnosti, kazališta i glazbe HAZU-a.

Benešić J. (J. B.), 1905: Oscar Wilde. “Obzor”, Zagreb, 27 May, pp. 1-2.

Bridgwater P., 1999: Anglo-German Interactions in the Literature of the 1890s. Oxford, University of Oxford.

Čale Feldman L., 2012: U san nije vjerovati. Zagreb, Disput.

Daalder J., 2004: Which is the Most Authoritative Early Translation of Wilde's "Salomé"? "English Studies", 1, pp. 47-52.

Galović F., 1940: Pjesme Frana Galovića. Zagreb, Binoza. 
Grubica I., 2010: The 'Byron of Kipling's England': Oscar Wilde in Croatia. In: S. Evangelista, ed.: The Reception of Oscar Wilde in Europe. London, Continuum, pp. 270-285.

Kohl N., 1989: Oscar Wilde: The Works of a Conformist Rebel. D. H. Wilson, trans. Cambridge, Cambridge University Press.

Kohlmayer R., 1995: From saint to sinner: The demonisation of Oscar Wilde's Salomé in Hedwig Lachmann's German translation and in Strauss' opera. In: M. Snell-Hornby, Z. Jettmarová, K. Kaindl, eds: Translation as Intercultural Communication: Selected Papers from the EST Congress - Prague 1995. Amsterdam/Philadelphia, John Benjamins Publishing Company, pp. 111-122.

Kohlmayer R. and Krämer L., 2010: Bunbury in Germany: Alive and Kicking. In: S. Evangelista, ed.: The Reception of Oscar Wilde in Europe. London, Continuum, pp. 270-285.

Lunaček V., 1906: Gostovanje gđice Ise Gregrove. “Obzor”, Zagreb, 24 May, p. 9. Medić I., 2017: Zavodljivi jezici - Krležina "Saloma” i vajldovski esteticizam. "Umjetnost riječi. Časopis za znanost o književnosti, izvedbenoj umjetnosti i filmu", vol. 61., 1/2, pp. 87-111.

Milčinović A., 1903: Zabranjene drame na njemačkim pozornicama. Vienac, Zagreb, 35.12, p. 387-390.

Kravar Z., 2001: Antički i moderni eros u lirskoj Salomi. In: N. Batušić, Z. Kravar, V. Žmegač, eds: Književni protusvjetovi. Poglavlja iz hrvatske moderne. Zagreb, Matica hrvatska, pp. 169-172.

Kravar Z., 2005: Svjetonazorski separei. Antimodernističke tendencije u hrvatskoj književnosti ranog 20. Stoljeća. Zagreb, Golden marketing i Tehnička knjiga. Krleža M., 1956: Davni dani: zapisi 1914-1921. Zagreb, Zora.

Krleža M., 1969: Poezija. Zagreb, Zora.

Wilde O., 1913: Sablast od Cantervilla. Zagreb, Kraljevska zemaljska tiskara.

Žmegač V., 1997: Duh impresionizma i secesije. Studije o književnosti hrvatske moderne. Zagreb, ZZKFFSZ.

\section{Igor Medić}

\section{Vajldomanija - prijevod Salomé Oscara Wildea i književnost hrvatske moderne}

SAŽETAK | Rad se bavi složenim učincima koje je pojava prijevoda drame Salomé irskoga književnika Oscara Wildea imala na književnost hrvatske moderne. Istražuje se utjecaj koji je iznimna popularnost Wildeova djela na njemačkome govornom području imala na piščevu recepciju u hrvatskoj kulturi, analizira se hrvatski prijevod njemačkoga prijevoda Salomé iz pera Hedwige Lachmann, koji su 1905. godine oblikovali Julije Benešić i Nikola Andrić, te se na primjeru djela Frana Galovića i Miroslava Krleže interpretira 
na koje je načine popularni vajldovski intertekst utjecao na modernizaciju stila hrvatske književnosti u razdoblju moderne, ne samo na razini posudbe pojedinih tipičnih motiva, likova ili stvaranja slična ugođaja nego i na razini razvoja osviještene jezične igre u pojedinim tekstovima.

KLJUČNE RIJEČI ～～Oscar Wilde, Salomé, prijevod, Fran Galović, Miroslav Krleža

\author{
Igor Medić
}

\title{
Wild about Wilde - The Translation of Oscar Wilde's Salomé in Croatian Literature of the Early 20th Century
}

SUMMARY | The paper deals with the complex effects the appearance of Oscar Wilde's play Salomé had on the literature of Croatian modernism. It explores the influence of the extreme popularity of Wilde's work in German-speaking countries on the author's reception in Croatian culture. The Croatian translation, which Julije Benešić and Nikola Andrić made in 1905 on the basis of Hedwig Lachmann's German translation of Salomé, is analysed and, based on the work by Fran Galović and Miroslav Krleža, it is interpreted how the famous Wildean intertext influenced the modernisation of style of Croatian literature in the period of early modernism, not only on the level of adoption of typical motifs, characters and atmosphere but also on the level of development of a self-reflective language play in some of the texts.

KEYWORDS | Oscar Wilde, Salomé, translation, Fran Galović, Miroslav Krleža

IGOR MEDIĆ | mag. educ., is a teacher of Croatian language in Gymnasium Clasicum in Zagreb. He graduated in Croatian language and literature and Comparative literature from the Faculty of Humanities and Social Sciences, University of Zagreb, where he is working, under the mentorship of Professor Lada Čale Feldman at the Postgraduate doctoral programme of Literature, Performing arts, Film and Culture, on a doctoral research entitled Oscar Wilde's Aestheticism and Croatian Literature of Early 20th Century. He is also working as an external associate at the Department of Comparative literature, collaborating on the scientific project Transmission, Resistance, Palimpsest: Text Re-figurations. He regularly participates in professional and scientific conferences and publishes works on Oscar Wilde, on the influence of Wilde's aestheticism on Croatian literature of the early 20th century and on Croatian modernism. 